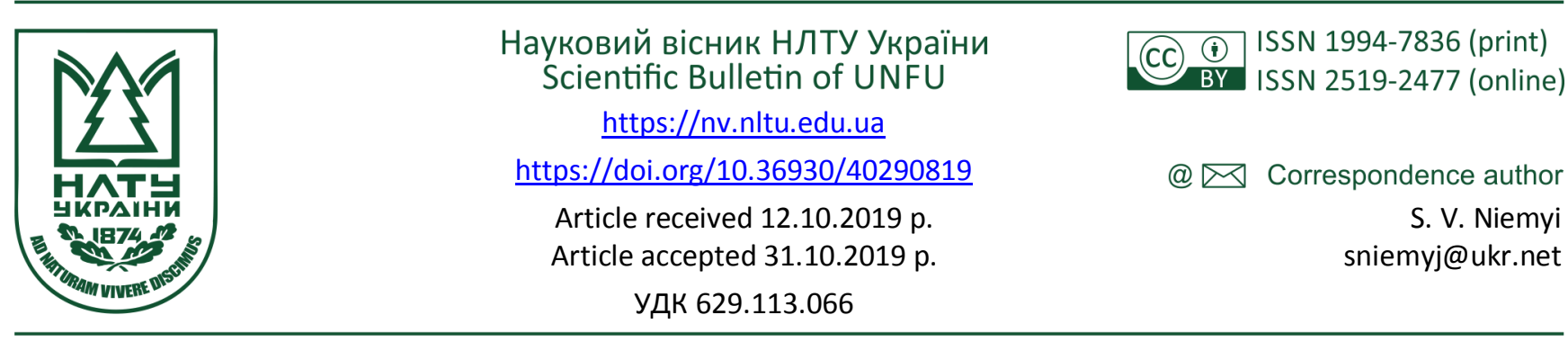

С. В. Нємий, В. М. Бритковський

Національний університет "Львівська політехніка", м. Львів, Україна

\title{
ПРОБЛЕМИ ОПТИМІЗАЦІЇ НАПРУГИ У БОРТОВІЙ МЕРЕЖІ ЕЛЕКТРООБЛАДНАННЯ АВТОТРАНСПОРТНИХ ЗАСОБІВ
}

\begin{abstract}
Проаналізовано вплив рівня напруги у бортовій мережі автотранспортних засобів на ефективність системи електрообладнання, зокрема на енергетичні витрати і безпеку експлуатації та технічного обслуговування. Доведено, що підвищення напруги у бортовій мережі автотранспортних засобів є вигідним в аспекті покращення енергетичних характеристик електричних машин, однак у класичних системах електрообладнання цього досягнути практично неможливо через потреба збільшення ваги акумуляторних батарей. Однією із важливих проблем, яка пов'язана із підвищенням напруги у системах електрообладнання автотранспортних засобів, $є$ безпека через ймовірність ураження водіїв і обслуговуючого персоналу електричним струмом високої напруги. Встановлено, що допустиме, за умовою безпеки, значення номінальної напруги у бортовій мережі системи електрообладнання автотранспортних засобів практично не повинна перевищувати 60 В. Підвищення рівня напруги у бортовій мережі сучасних автотранспортних засобів із традиційними системами електростартерного пуску двигунів зі свинцево-кислотними акумуляторними батареями практично вичерпується значенням 24 В, оскільки надалі вага акумуляторних батарей стає неприпустимо великою. Проблема збільшення величини бортової напруги автотранспортних засобів можна радикально вирішити лише під час переходу на електричні джерела стартерного пуску двигунів інших типів, наприклад ємнісні нагромаджувачі.
\end{abstract}

Ключові слова: система електрообладнання; акумуляторні батареї; величина напруги; енергетичні характеристики; електрична безпека; конденсаторний пуск.

Вступ. Одним із основних напрямів удосконалення конструкцій автомобільних транспортних засобів (АТЗ) є роботи 3 мінімізації енергоспоживання. Енергоспоживання АТЗ визначається як досконалістю двигунів, так і експлуатаційною ефективністю агрегатів і систем АТЗ та його конструктивними особливостями. Однак комплексний вплив на енергоспоживання АТЗ зазначеними чинниками досліджено недостатньо.

Експлуатаційна ефективність системи електрообладнання (CEO) АТЗ залежить від характеристик джерел електроенергії та функціональних властивостей виконавчих електричних пристроїв: стартерів, електродвигунів, освітлювальних приладів тощо. Зокрема, як показують дослідження (Nemyi \& Britkovsky, 2014; Nemiy, 2015; Khortov, 1993; Schmidt, 1994), значний вплив на експлуатаційну ефективність системи електрообладнання має величина напруги у бортовій мережі АТЗ. Однак комплексний вплив величини напруги у бортовій мережі АТЗ на ефективність системи електрообладнання, зокрема на енергетичні витрати і безпеку експлуатації та технічного обслуговування, досліджено недостатньо.

Виходячи із принципу декомпозиції, в аспекті експлуатаційної ефективності, автомобільний транспортний засіб (АТЗ) можна відобразити структурно схемою (Nemyi \& Britkovsky, 2014) (рис. 1).

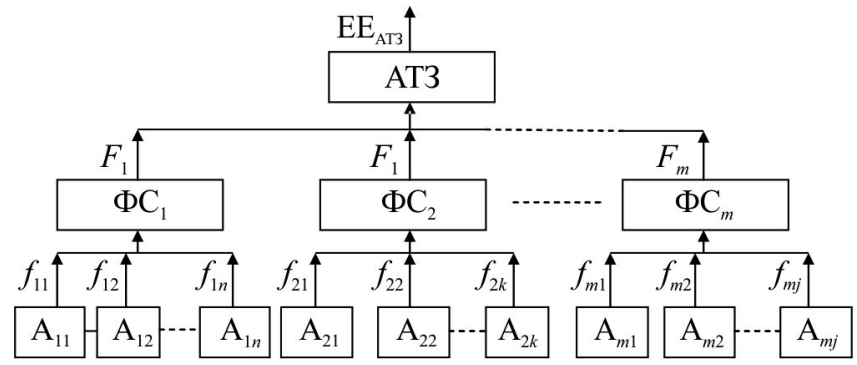

Рис. 1. Структурна схема експлуатаційної ефективності АТЗ: $A$ - складова частина (агрегат) функціональної системи (ФС); $f$ - робочі характеристики складових частин (агрегатів); $F$ - робочі характеристики функціональних систем; $E E_{A T 3}-$ експлуатаційна ефективність АТЗ

На цій структурній схемі бачимо, що експлуатаційна ефективність АТЗ залежить від робочих характеристик функціональних систем, які формуються робочими характеристиками складових частин (агрегатів) (Nemyi \& Britkovsky, 2014).

Метою роботи є аналіз результатів сучасних досліджень ефективності роботи системи електрообладнання бортових мереж автомобільних транспортних засобів (АТ3) залежно від рівня напруги, зокрема: впливу напруги електрообладнання на енергетичні витрати, безпеку експлуатації та технічне обслуговування АТЗ.

\section{Інформація про авторів:}

Нємий Степан Володимирович, канд. техн. наук, доцент, кафедра експлуатації та ремонту автомобільної техніки.

Email: sniemyj@ukr.net

Бритковський Василь Михайлович, канд. техн. наук, доцент, кафедра експлуатації та ремонту автомобільної техніки. Email: v.brykovskyi@gmail.com

Цитування за ДСТУ: Нємий С. В., Бритковський В. М. Проблеми оптимізації напруги у бортовій мережі електрообладнання автотранспортних засобів. Науковий вісник НлтУ України. 2019, т. 29, № 8. С. 106-109.

Citation APA: Niemyj, S. V., Brytkowskyi, V. M. (2019). The optimization problem onboard network voltage in the vehicle electrical appliances. Scientific Bulletin of UNFU, 29(8), 106-109. https://doi.org/10.36930/40290819 
Аналіз відомих рішень і публікацій. У роботі (Nemyi \& Britkovsky, 2014) розглянуто енергетичну ефективність сучасних систем електростартерного пуску автомобільних двигунів у аспектах коефіцієнта корисної дії системи щодо використання хімічної енергії палива та експлуатаційних витрат пального.

У публікації (Nemiy, 2015) розглянуто проблему енергетичної ефективності АТЗ у системному зв'язку витрат енергії двигуна для забезпечення руху та живлення допоміжних агрегатів і функціональних систем. Систематизовано і наведено структуру витрат енергії двигунів автомобільних транспортних засобів. Наведено основні чинники, що впливають на їхню енергетичну ефективність. Відзначено, що оптимізація режимів роботи і характеристик допоміжних агрегатів дасть змогу знизити витрати потужності двигунів та сприятиме покращенню паливної ощадності автомобільних транспортних засобів.

У публікації (Khortov, 1993) розглянуто перспективи застосування конденсаторів у високовольтній системі електростартерного пуску двигунів АТЗ. Однак проблему захисту персоналу від високої напруги практично не розглянуто. У роботі (Schmidt, 1994) висвітлено результати досліджень впливу напруги на людський організм та обгрунтовано їі допустимий, в аспекті безпеки, рівень.

Викладення основного матеріалу. Як відзначено у роботі (Nemiy, 2015), основними чинниками, що впливають на енергетичну ефективність АТЗ, є споживання енергії агрегатами і функціональними системами та їхня власна вага. Тому що проблему розглянемо стосовно CEO в аспекті впливу рівня напруги на вагу та споживання енергії комплектуючими електрообладнання. Щодо ваги, то тут маємо на увазі вагу проводів електромережі, а основними комплектуючими, які споживають енергію двигуна, $є$ стартери, генератори та світлотехнічні прилади.

За однакової споживаної потужності виробів електрообладнання АТЗ, виходячи 3 відомої залежності 3 електротехніки $(U=I R)$ (Gerasimov et al., 1983), у разі підвищення рівня напруги можна очікувати певного зменшення споживаного струму та, відповідно, поперечного перерізу проводів, а відтак - i ваги проводів електромережі. Однак на практиці під час переходу з напруги 12 В на напругу 24 В зменшення ваги електропроводки практично не відбувається. Наприклад, на середньому бензиновому автобусі (12 В) маса електропроводки становить 51,3 кг, а на середньому дизельному автобусі (24 В) маса електропроводки становить 48,5 кг.

Це пояснюємо насамперед тим, що застосування проводів, пропорційно зниженню розрахункової сили струму, зменшеного перерізу обмежується їх механічною міцністю, наприклад, у автобусів мінімальний переріз застосовуваних проводів становить $0,75 \mathrm{~mm}^{2}$. I найголовніше, за цього переходу номіналу напруги 3 12 на 24 В у класичних СЕО автобусів конструктивна вага навпаки різко збільшується через подвоєння кількості стартерних акумуляторних батарей. Наприклад, для зазначених вище автобусів, за системи $12 \mathrm{~B}$ маса акумуляторної батареї становить 60 кг, за системи 24 В - відповідно 120 кг, тобто виграш завдяки зменшенню ваги електропроводки 3 надлишком "з'їдається" збільшенням маси акумуляторних батарей.

Інша річ із впливом підвищення напруги у бортовій мережі на енергетичні показники електричних машин - стартерів, генераторів і електродвигунів допоміжного електрообладнання. Для прикладу, на рис. 2 наведено характеристики електричної машини типу стартера СТ222 залежно від номінальної напруги у бортовій мережі (Schmidt, 1994).

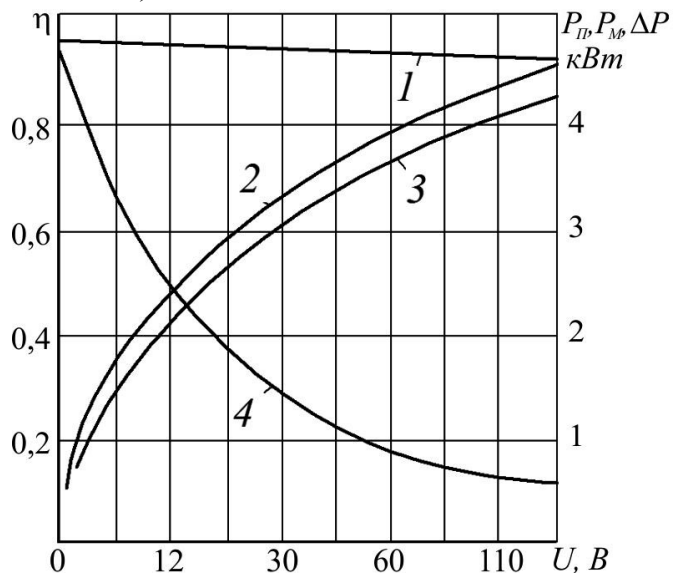

Рис. 2. Залежність характеристик електричної машини типу стартера СТ-222 залежно від номінальної напруги у бортовій мережі: 1) споживана потужність $P_{n}$; 2) коефіцієнт корисної дії п; 3 ) максимальна корисна потужність $\left.P_{M} ; 4\right)$ втрати у стартері $\Delta P$

У разі зміни номінальної напруги живлення у діапазоні від 12 до 220 В ККД стартера зростає від 0,455 до 0,88 , а максимальна потужність - від 2,2 до 4,21 кВт. Окрім цього, за підвищення напруги струм, що протікає через стартер, $є$ значно меншим, завдяки чому щіточноколекторний вузол конструктивно спрощується і стає більш надійним. Наприклад (Schmidt, 1994), за напруги 110 В електростартер СТ-222 споживає не, як звичайно, $500 \mathrm{~A}$, а всього $55 \mathrm{~A}$.

Також завдяки збільшенню напруги у бортовій мережі АТЗ покращуються енергетичні характеристики генераторів. На рис. 3 наведено відповідні порівняльні дані (Nemiy, 2015): ККД генератора напругою $24 \mathrm{~B}$ більш ніж в 1,2 раза перевищує ККД генератора напругою $12 \mathrm{~B}$.

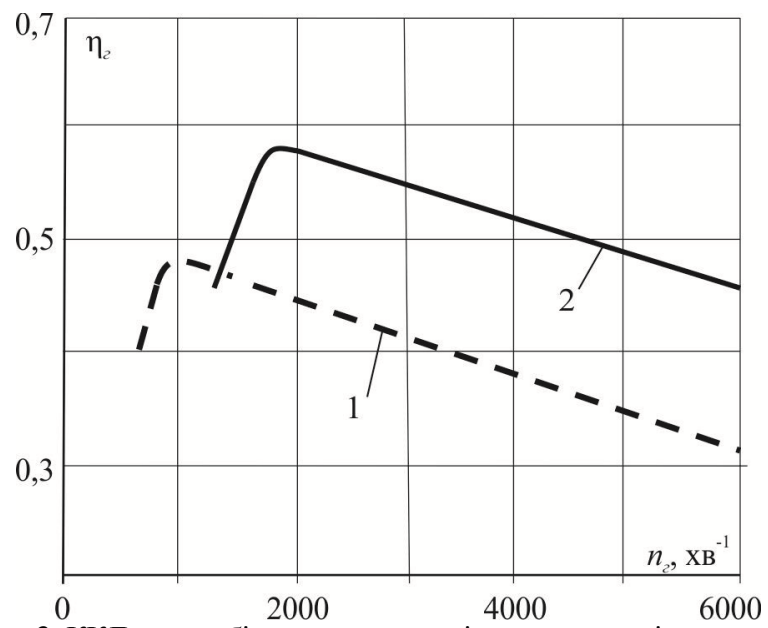

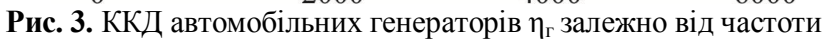
обертання їх роторів $\Pi_{\Gamma}$ : 1) Г287 (12 B); 2) 65,701 (24 В)

Отже, підвищення напруги у бортовій мережі АТЗ $є$ вигідним в аспекті покращення енергетичних характеристик електричних машин, однак у класичних СЕО цього досягнути неможливо через потреба збільшення ваги акумуляторних батарей.

Радикальним рішенням цієї проблеми впродовж останніх років $є$ відмова від традиційних систем електростартерного пуску двигунів зі свинцево-кислотними аку- 
муляторними батареями (Khortov, 1993; Akimov \& Chizhkov, 1994). Одним із таких рішень є застосування конденсаторних систем пуску з ємнісними нагромаджувачами.

На відміну від традиційних систем електростартерного пуску номінальною напругою 12 і 24 В, системи із застосуванням конденсаторів дають змогу перейти на більш високі напруги в системах пуску. Це особливо актуально з огляду на постійне збільшення потужності ДВ3 і, відповідно, збільшення пускових струмів у стартерних колах до 2000 A (Khortov, 1993). Окрім цього, як уже зазначали, ККД електростартерів сучасних систем пуску є доволі низькими: 0,45-0,55. Це свідчить про те, що на живлення системи електростартерного пуску двигунів витрачається практично вдвічі більше енергії, ніж це потрібно для прокручування вала двигуна.

Збільшується також віддача акумуляторної батареї за ємністю, оскільки в системах пуску з ємнісними нагромаджувачами вона працює безпосередньо не на електростартер, а на заряд конденсаторної батареї, коли від неї відбирається струм, на порядок менший, ніж у класичній системі пуску. У цьому випадку можна застосовувати батарею меншої ємності або допускати іiї значний розряд, що є неможливим у класичній системі пуску. З'являється можливість використання будь-яких типів акумуляторних батарей, а не лише стартерних. Окрім цього, віддача конденсаторної батареї під час переходу на високу напругу різко збільшується і завдяки застосуванню звичайних електролітичних конденсаторів з енергії становить 99,9 \% (Khortov, 1993).

Однак однією із важливих проблем, яка пов'язана 3 підвищенням напруги у СЕО АТЗ, є безпека - ймовірність ураження водіїв і обслуговуючого персоналу АТП i CТО електричним струмом високої напруги, адже повністю виключити контакт водія автомобіля чи технічного персоналу з електричним струмом -нереально. Фізіологічний вплив електричного струму на тіло людини призводить до важких травм і навіть смерті. Для вирішення цієї проблеми група спеціалістів SAE (США) розглянула й узагальнила результати всіх, раніше виконаних досліджень $з$ оцінки допустимої величини електричного струму, що проходить через людське тіло (Schmidt, 1994).

Таблиця. Вплив змінного і постійного струму на організм людини

\begin{tabular}{|c|l|l|}
\hline \multirow{2}{*}{ Сила струму, А } & \multicolumn{1}{|c|}{ Вплив на організм людини } \\
\cline { 2 - 3 } & \multicolumn{1}{|c|}{ змінний струм частотою 50 Гц } & \multicolumn{1}{|c|}{ постійний струм } \\
\hline $0,0006-0,0015$ & слабке свербіння, пощипування шкіри & не відчувається \\
\hline $0,002-0,004$ & відчуття поширюється, злегка зводить м'язи & не відчувається \\
\hline $0,005-0,007$ & больові відчутя посилюються, судороги & слабке нагрівання шкіри \\
\hline $0,008-0,01$ & сильний біль, судоми, руки важко відірвати від провідників & нагрівання посилюється \\
\hline $0,01-0,015$ & нестерпний біль, руки неможливо відірвати від провідників & нагрівання посилюється ще більше \\
\hline $0,020-0,025$ & $\begin{array}{l}\text { сильний біль, руки паралізуються, їх неможливо відірвати } \\
\text { від провідників, ускладнюється дихання }\end{array}$ & $\begin{array}{l}\text { шкіра нагрівається, відчувається внутрішнє } \\
\text { нагрівання, скорочуються м'язи рук }\end{array}$ \\
\hline $0,05-0,06$ & параліч дихання; порушується робота серця & $\begin{array}{l}\text { сильне нагрівання; руки не можливо відір- } \\
\text { вати від провідників }\end{array}$ \\
\hline $0,08-0,1$ & параліч дихання & параліч дихання, фібриляція серця \\
\hline 0,3 & швидкий параліч дихання & $\begin{array}{l}\text { параліч дихання; протягом } 3 \text { с і більше - } \\
\text { фібриляція серця }\end{array}$ \\
\hline
\end{tabular}

Як бачимо у таблиці, небезпечним для людини є змінний струм силою $0,01 \mathrm{~A}$ i більше, постійний струм - 0,05 А і більше. Це свідчить про те, що у СЕО доцільно використовувати постійний струм, оскільки він є безпечнішим (Chizhkov \& Maleev, 1994; Nabokikh, 2002).
Внаслідок цього створили графіки фізіологічного впливу на людський організм електричного струму (рис. 4), залежно від його величини і тривалості дії (Schmidt, 1994).

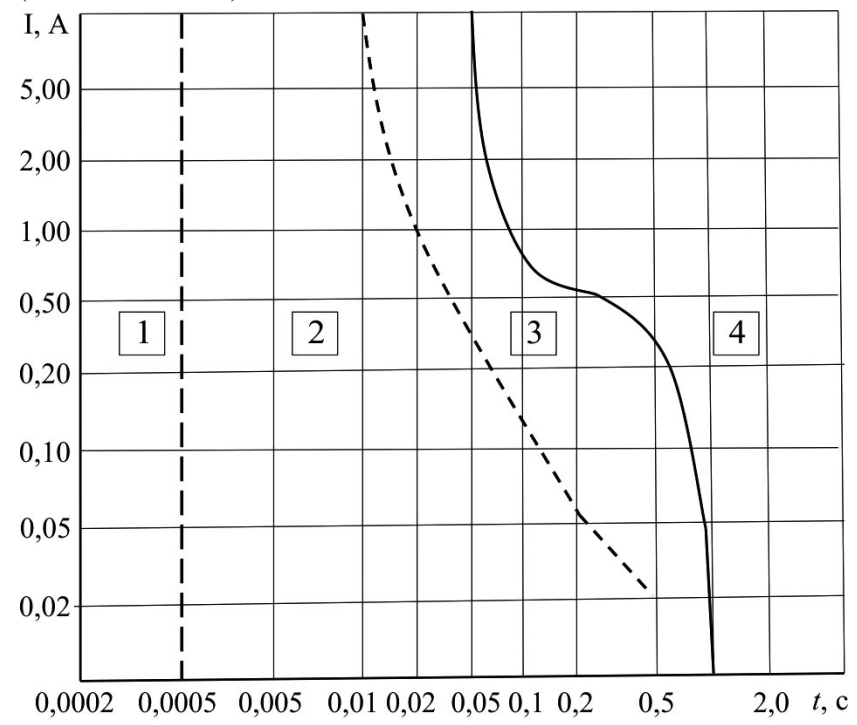

Рис. 4. Графік фізіологічної дії постійного електричного струму на організм людини: 1) зона нечутливості; 2) зона без шкідливої дії; 3) зона можливих м'язових скорочень, утруднення дихання і дії на серце; 4) зона травматичних і важких фізіологічних наслідків

На рисунку чітко виділяються чотири зони впливу: 1 - відсутність реакції людини; 2 - відсутність шкідливої дії; 3 - відсутність органічних пошкоджень, але $є$ ймовірність м'язових скорочень і утруднення дихання, зворотних порушень від утворення і передачі імпульсів на серце; 4- важких фізіологічних наслідків (аж до смертельного травмування).

Окрім сили струму і часу його дії, ступінь ризику визначаємо також площею контакту і значенням внутрішнього електричного опору людського тіла. Встановлено, що у $95 \%$ людей внутрішній електричний опір становить 1250 Ом, в інших $5 \%$ населення - дещо менший (Schmidt, 1994). У таблиці наведено ступінь шкідливої дії змінного і постійного струму на організм людини (Gerasimov et al., 1983).
Виходячи 3 наведених статистичних даних щодо внутрішнього електричного опору людського тіла, прийнявши його значення $R_{l}=1250$ Ом і значення небезпечної для людського організму величини струму $I=$ 0,05 А (див. рис. 3), за відомою із електротехніки залежністю (Gerasimov et al., 1983), отримаємо допусти- 
ме, за умовою безпеки, значення бортової напруги у CEO AT3:

$$
U=I R \leq 0,05 \cdot 1250 \leq 62,5 \mathrm{~B} .
$$

Як бачимо із цього елементарного розрахунку, допустиме, за умовою безпеки, значення напруги у системі електростартерного пуску ДВ3, а відтак і номінальна напруга у бортовій мережі СЕО АТЗ практично не повинна перевищувати 60 В.

\section{Висновки:}

1. Завдяки збільшенню величини бортової напруги значно покращуються експлуатаційні характеристики електричних машин CEO, що сприяє покращенню паливної ощадності АТЗ.

2. Підвищення рівня напруги у бортовій мережі сучасних АТЗ із традиційними системами електростартерного пуску двигунів зі свинцево-кислотними акумуляторними батареями практично вичерпується значенням 24 В, оскільки надалі вага акумуляторних батарей стає недопустимо великою.

3. Проблему збільшення величини бортової напруги АТЗ можна радикально вирішити лише під час переходу на електричні джерела стартерного пуску двигунів на інші типи, наприклад ємнісні нагромаджувачі.

4. Однак за всіх наведених вище превагах підвищення рівня бортової напруги СЕО АТЗ виникає значна проблема гарантування безпеки експлуатації автотранспортних засобів щодо ураження людей електричним струмом високої напруги, через що допустиме, в аспекті безпеки персоналу, номінальне значення рівня напруги у бортовій мережі АТЗ не повинно перевищувати $60 \mathrm{~B}$.

\section{Перелік використаних джерел}

Akimov, A. V., \& Chizhkov, Yu. P. (1994). Secondary energy source for capacitor starting system. Automotive industry, 4, 8-10. Moscow. [In Russian].

Chizhkov, Yu. P., \& Maleev, R. A. (1994). Calculation of a starting system with capacitive energy storage. Automotive industry, 9, 3132. Moscow. [In Russian].

Gerasimov, V. G. (Ed.), Seidel, H. E., Kogen-Dalin, V. V., et al. (1983). Electrical Engineering. Moscow: Higher school, 480 p. [In Russian].

Khortov, V. P. (1993). High-voltage engine start systems. Automotive industry, 6, 20-22. Moscow. [In Russian].

Nabokikh, V. A. (2002). Conceptual electrical equipment of cars. $A u$ tomotive industry, 10, 4-6. Moscow. [In Ukrainian].

Nemiy, S. V. (2015). Energy structure of a motor vehicle. (Ser. Dynamics, Durability and Design of Machines and Devices). Bulletin of the National University "Lviv Polytechnic", 820, 90-96. Lviv: Publishing House "Lviv Polytechnic". [In Ukrainian].

Nemyi, S. V., \& Britkovsky, V. M. (2014). Energy efficiency of electric starter starter system. (Ser. Dynamics, Durability and Design of Machines and Devices). Bulletin of the National University "Lviv Polytechnic", 788, 37-42. Lviv: Publishing House "Lviv Polytechnic". [In Ukrainian].

Schmidt, A. G. (1994). How much to increase the voltage in the vehicle's electrical system. Automotive industry, 12, 33-35. Moscow. [In Russian].

S. V. Niemyj, V. M. Brytkowskyi

Lviv Polytechnic National University, Lviv, Ukraine

\section{THE OPTIMIZATION PROBLEM ONBOARD NETWORK VOLTAGE IN THE VEHICLE ELECTRICAL APPLIANCES}

The purpose of this work is to analyze the effect of the voltage level in the onboard network of vehicles on the efficiency of the electrical system, in particular on energy costs and safety of operation and maintenance. It is proved that increasing the voltage on the onboard network of vehicles is advantageous in terms of improving the energy performance of electric cars, but in classical electrical systems it is almost impossible to achieve this because of the need to increase the weight of batteries. In practice, when switching from $12 \mathrm{~V}$ to $24 \mathrm{~V}$, there is practically no reduction in the weight of the wiring and the weight of the elements of the electrical system. For example, when switching the voltage rating from 12 to $24 \mathrm{~V}$ in classic car electrical systems, the structural weight on the contrary increases sharply due to the doubling of the number of starter batteries. One of the important problems associated with increasing the voltage in the vehicle electrical system is safety due to the likelihood of drivers and service personnel being electrocuted by high voltage, since completely eliminating the contact of the driver of the car or technical personnel with the electric current is unrealistic. It is established that the permissible, for safety condition, the value of the rated voltage on the on-board network of the vehicle electrical system should not practically exceed $60 \mathrm{~V}$. Increasing the level of voltage in the onboard network of modern vehicles with traditional electrostarter starter batteries with lead-acid batteries is virtually exhausted by $24 \mathrm{~V}$, since in the future the weight of the batteries becomes unacceptably large. The problem of increasing the amount of on-board voltage of vehicles can be radically solved only when switching to electrical sources of start-up engines for other types, such as capacitive storage units. With all the advantages of increasing the level of on-board voltage of the vehicle electrical system, there is a significant problem of guaranteeing the safety of the operation of motor vehicles in relation to the electric shock of high voltage, which is why, in the aspect of personnel safety, the nominal value of the voltage level in the on-board network of vehicles should not exceed $60 \mathrm{~V}$.

Keywords: system of electrical equipment; rechargeable batteries; magnitude of voltage; energy characteristics; electrical safety; capacitor start. 